\title{
The Domination of the Local Party of Aceh Parliament in Responding the Aspiration of Community
}

\author{
Sayed Amirulkamar ${ }^{1}$, Ismail ${ }^{1}$ \\ ${ }^{1}$ Iskandar Muda University (UNIDA), Aceh, Indonesia \\ ismail.unida@gmail.com
}

\begin{abstract}
The Unitary State of the Republic of Indonesia as a country of island diversity, culture, ethnicity, language and others which makes Indonesia political power does not adhere to the system of any country, but adopts the existence of the order of life of the Indonesian people by combining the "Trias Politica" government system, which presents by Montesquieu who was born on 18 January 1689 and died on February 10, 1755 at the age of 66, (French political thinkers) who lived in the Age of Enlightenment (English: Enlightenment) which describes power with the term "Separation of power" into three powers there are "Legislative" (Making Laws), "Executives" (Acting Laws) and "Judicative" (Overseeing the laws) and not division of power. With this authority politically everyone understands the Legislative Election in Aceh, it different from legislative elections in various provinces in Indonesia, the difference in Aceh is that there are a number of local political parties who have competed in democratic parties since 2009. As for the legislative elections to the period 2019-2024 who have passed the verification of 4 (four) local political in the Aceh Party (PA), the Nanggroe Aceh Party (PNA), the Aceh Regional Party (PDA), and the SIRA Party who compete competitively for parliamentary seats (DPRA / DPRK).
\end{abstract}

Keywords: local part; aspiration of community; Aceh

\section{Introduction}

Nowadays if we look closely at the problems of life of the nation and state it becomes very important to be discussed continuously, because it becomes the main and warm topic that needs to be discussed, especially speaking political power as a public vehicle that is directly related to the nation and state while talking politics itself means we enter realm of the political system. In this connection the dominance of local political parties in the Acehnese parliament in responding to the aspirations of the people is still a "slogan" and "jargon" of life in serving the developing political system. 
The nation's historical journey in Aceh in the party needs to be well maintained as a connector for the political aspirations of the people from their respective electoral districts (Dapil) so as to be able to address the existence of the overall needs of the community while occupying the Aceh parliamentary seat. In the elaboration of the implementation of the local party (Local party) it is intended to regulate the local political parties as participants in the general election relating to the provision of space for political participation of the Acehnese community for the benefit of Acehnese members and the state. This is an effort to create national and regional politics that is carried out in a healthy, competitive, participatory and fair manner.

The 30-year war was followed by the Aceh earthquake and tsunami on Sunday 26 December 2004 and the MOU Helsinki began signed on Monday 15 August 2005 on behalf of the Government of the Republic of Indonesia Hamid Awaluddin Minister of Law and Human Rights, and also on behalf of the Leader of Free Aceh Movement, Malik Mahmud. Then by changing the system that was built so that a safe and peaceful situation was realized in Aceh through the signing of point 1.2.1 of the MOU Helsinki, by GAM and RI on 15 August 2005 that as soon as possible not more than one year after the signing of the Memorandum of Understanding this, the Government of Indonesia agreed and would facilitate the formation of political parties based in Aceh that met national requirements.

In carrying out the widest possible autonomy, the Acehnese community also has a role, both in planning, formulating, stipulating and evaluating regional government policies that have not been implemented properly as an example of the absence of 2018 APBA agreements between executives and legislative so that it ends with a Governor Regulation Aceh. But the flashback long before the local party had many solutions made by the government in Aceh's peace efforts, but natural disasters, earthquakes and tsunamis had many difficulties at that time by losing everything that happened in Aceh had fostering the solidarity of all potentials of the nation to rebuild the people and regions of Aceh.

Basically the dialectic of local political power is "Centralization and" Decentralization ", this is because the issue of regional politics is inseparable from the local political power that exists in the area, especially in the context of regional autonomy in accordance with the authority of the central government to delegate its authority to the regions. 


\section{Review of Literatures}

\subsection{Signs of Local Political Parties}

\section{a. Life of Local Parties in an Area}

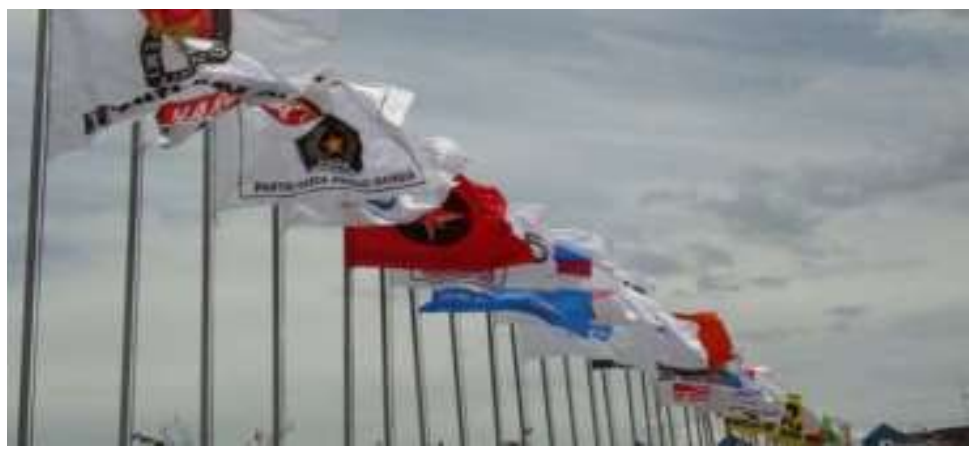

Source: Kompas.Com

Picture: Party flags

The political condition of Aceh in this time, four parties will fight for seats in the DPRK, DPRA. They compete with cadres of national political parties.

\section{b. Early Formation}

The formation of Local Party in Aceh can be called a part of prolonged conflict compensation. This is explained in point 1.2 of the peace agreement signed by the MOU Helsinky. Then, the results of the negotiations and agreements are contained in Law No. 11 of 2006 concerning the Government of Aceh, or better known as the UUPA, concerning the permissibility of the formation of political parties referred to in Article 75.

In line with that, the Central Government also issued Government Regulation (PP) Number 20 of 2007 concerning Aceh Local Political Parties. In the regulation it was stated, legalizing the establishment of local political parties in Aceh in a juridical manner, had been very strong, namely with consideration (consideration) of the 1945 Constitution articles 28 and 18A.

1. Parenting Register

The 2009 legislative election was the first year of existence of local party in Aceh. Long before that, since 2007 a number of Acehnese political parties were formed. Initially the formation of 14 Local Political Parties had registered with the 
Department of Law and Human Rights. But at that time, KIP Aceh only passed six local political party, they strolled into the Legislative Election (Pileg) in 2009 because they were declared to meet the verification requirements.

Of the six parties, the PA claimed the only party that overshadowed former Free Aceh Movement (GAM) combatants. And, PA managed to show as a new local party that succeeded in gaining victory by attracting sympathy from the Acehnese people. How not, the results of the 2019 legislative election were truly shocking, PA dominated the results at that time. The Aveh Party (PA) is able to defeat the national party, even believed, the results PA made in the 2009 legislative elections have never been achieved by other political parties in Indonesia since the first democratic party began in the election to elect DPR members held on 29 September 1955 followed by 29 Political parties and individuals. While the second stage of the election is to elect a constituent member which is held on December 15, 1955.

2. The dynamics of the party's life is very varieties both the National Party (Parnas) and the local Party in obtaining parliamentary seats Aceh. As the article on serambinews.com with the title Four Local Parties Return to Election, This History Has Drowned Local party in Aceh, PA managed to get $46.91 \%$ of the votes, they succeeded in occupying 33 seats out of 69 seats at the DPRA at that time.

3. Only Three Parliaments in 2014 Legislative Election, in the number of six parties who previously participated in the 2009 legislative election, it turned out that not all of them returned to the 2014 legislative election. The reason was that all six parties did not fulfill the conditions to participate again, or now known as the parliamentary threshold as a threshold for the minimum vote for political parties in general elections to be included in the determination of seats in the People's Representative Council (DPR-RI) and the House of Representatives and the Regional Representatives Council (DPD-RI).

When seen the development, the Aceh Party (PA) and the Aceh Regional Party (PDA) can participate again while the other 5 (five) parties fail to become political parties. But in 2014 the Legislative Election (Pileg) emerged a new party, namely the party made by Irwandi Yusuf, Sofyan Dawood, and friends, with the new name The Party was named with 
the Aceh National Party (PNA). In the 2014 Pileg, the threeparties received sequential numbers, PDA number 11, PNA number 12, and PA number 13. Especially in Aceh, at that time, these three parties competed with 11 national parties to get seats in parliament. Again, the PA dominated, with the most votes, from 81 seats in the DPRA as many as 29 seats, equivalent to 35.80 percent $(\%)$. even though they were admitted to have slightly decreased their votes compared to the 2009 legislative elections. The PNA only received 3 seats or 3.70 percent (\%). Likewise PDAs, only able to win one seat or 1.23 percent $(\%)$.

For the 2019 Election, two parties: the PDA and PNA, were forced to change their names, logos and symbols because they did not meet the requirements or did not reach at least five percent of seats in the DPRA in the previous legislative election. This is as stipulated in Article 90 of the BAL. Whereas the PA, is certainly free of obstacles, even the PA does not need to be verified factually by KIP as it is for other parties. The reason is because the PA has fulfilled the requirements, obtaining at least five percent of seats in the DPRA.

\section{Research Methods}

This study is conducted by qualitative descriptive research. Descriptive research is a study that is intended to provide an overview of the state of the subject / object of research as it is. Research that seeks to explain the problem solving that is now based on data. In addition qualitative research is a study that produces written or oral data.

\section{Discussion}

The political dominance of power will occur along with the history of the nation in the political dynamics in Indonesia and Aceh, especially the rise and fall of political parties is not a big problem because:

a. The democracy chart is wide open and its euphoria is still buzzing;

b. The existence of the concept of special autonomy is exalted, along with the ideals of decentralization;

c. The emergence of the practice of transactional politics and political dynasties is under the influence of decentralization and not only in local governments but in the realm of political parties 
As for the various elements of community who elect members of the legislature in the legislative election, it is not certain that all of them can be fulfilled wholeheartedly, on the one hand, political parties are increasingly emerging and developing into election participants. If you look at the existence of law Number 23 Year 2014 in conjunction with the Government Regulation in Lieu of Law Number 2 Year 2014 in conjunction with Law number 9 of 2015 concerning the Second Amendment to Law number 23 of 2014 concerning regional government, then decentralization to the regions is surrender of government authority by the government to autonomous regions to regulate and manage government affairs in the system of the unitary state of the Republic of Indonesia.

Clearly regional autonomy in the perspective of decentralization has a loose role (dekresi) in making policies, regulating, implementing and controlling the affairs that are the affairs of their respective regions. The condition when examined shows decentralization as a principle of transfer of authority in the context of administering government which is always contradicted by the principle of centralization, this leads to the existence of "local government", this condition occurs because "superior government" is caused by the division of authority and the availability of space sufficient to interpret the authority given to lower government units (local government).

In the elaboration and action of local political parties that control the parliamentary seats directly obtain a majority vote so that everything done personally has won but because the parliament is known for the faction's voice and not personal so that everything keeps referring to Government Regulation No. 16 of 2010 concerning the Guidelines Preparation of the Board of Regulations which in turn the Aceh Parliament also guided the Decree of DPRA Number 1 of 2014 concerning DPRA Rules of Procedure.

With the existence of a binding legal reference, it is necessary to have harmony established by the Aceh Government along with the Aceh Parliament (DPRA) which is dominated by the Local Party and supported by the National Party in maintaining the Unitary State of the Republic of Indonesia from Sabang to Meuroke. Therefore, it often makes political disputes among elites in understanding decentralization in planning policies, so that as silalahi and syafri (2015: 88) mention the following:

a. Centralization and decentralization with regard to the distribution of power or authority of government to manage regional government and public administration;

b. Centralization is a concentration of power on the government and central administration to 
manage the area; the opposite;

c. Decentralization is the concentration of power on the government and regional administration or the distribution of power to the regions to manage the regions.

In the paradigm of the decentralization government, the government's authority to govern governors as representatives of the government and / or to vertical agencies in certain regions, has not been able to fully contribute to the community because on the second hand is influenced by local parties that dominate parliamentary seats on the other side directly elected (Pilsung) from the community in (Jurdil).

In the view of Himawan in Halim (2014: 26) mentioning that the discussion on local politics cannot be released from the principle of decentralization which became the basis for the formation of the Regional Government. Therefore the content of decentralized meaning as seen by Silalahi and Syafri (2015: 93) states that Decentralization as the transfer of power from higher levels to lower levels, this transfer can be seen from the form and degree of power.

In the silence of the distribution of government power to the regions, centralization and decentralization are concerned with the distribution of power or authority between the central government and the regional government to manage the government well. In general, as Silalahi and Syafri (2015: 88-89) states that Centralization is the concentration of power on the government and central administration to manage the regions, while decentralization is the concentration of power on the government and regional administration or the distribution of power to the regions to manage the regions.

It is clear to us to show the broadest possible autonomy in the field of politics to Acehnese people and to manage regional government in accordance with the principles of good governance, namely transparent, accountable, professional, efficient and effective, intended to maximize the prosperity of the people in Aceh, not for individuals or groups power.

Decentralization, Wasistiono (2009: 6) states that "The universal principle of democracy is" from the people, by the people and for the people", therefore through this principle concentrated government systems are developed as" biological children "of democracy. The essence of decentralization is "solving local problems, by local means, and by local people ${ }^{8}$. Thus the understanding of regional autonomy in its logical consequence as a unitary state is the establishment of the Indonesian state government as the national government to form a region in accordance with Article 18 paragraph (2) and (5) of the 1945 Constitution. According to the principle of autonomy and co-administration and given the widest possible autonomy. 
This description makes prospect the life of democracy through awareness of politics and the state's political order.

Regulatory regulations

1. Law number 9 of 2015 concerning the second amendment to law number 23 of 2014 concerning regional government pursuant to article 409 revoked law number 32 of 2004 as amended several times, the latest by law number 12 of 2008 about regional government.

2. Article 312 (1) and article 45 (1) of government number 58 of 2005 concerning regional financial management affirms that regional heads and must agree together with a number of regional regulations about no later than 1 (one) month before the start of the fiscal year each year.

Circular number 13 of 2014 concerning simple life movements

a. Limiting the number of reception invitations for organizing events such as weddings, gatherings and other similar events a maximum of 400 invitations and limiting the number of participants present to more than 1,000 people.

b. Do not show excessive luxury and / or attitude of life and pay attention to the principles of propriety and appropriateness as a sense of empathy to the community.

c. Do not provide essays to superiors or fellow government officials.

The task of assistance is the assignment from the government to the regions and / or villages from the provincial government to the districts / cities / or villages and from the provincial government to the districts / cities / or villages and from the district / city government to the villages to carry out certain tasks.

\section{Conclusion}

Basically all political parties in a country are not much different from the history of democratization with western societies with developing countries who struggle to fight for themselves to escape the grip of colonial colonists such as Spain, Portugal, England and Netherlands in the countries of the Liberia Peninsula (South America) or known as the country of Argentina, Brazil \& Chile, always turbulent with the turmoil of local politics in contrasting between the capitalist powers of the latifundistas (landlords) and revolutionary socialists fighting in the name of the people. Whereas in countries in Africa \& East Asia, the journey to 
democracy in their society is full of struggles of ethnic groups fighting over widespread sources of livelihood in their territory.

In Indonesia, the history of local politics is almost as old as the age of colonial rule, decentralization of power, and government administration itself. Even if we trace far back, to the era of the kingdom that once stood majestically throughout the archipelago, the nobles used local politics to expand their territory and power. So that local politics can be said is not a new item in the history of the formation of the character of the nation and state until the second this writing is made. The history of local politics is divided into several stages, namely: Dutch colonial rule; Japanese colonial rule; post-independence in 1945; the Republic of Indonesia union in the years 1948-1949; parliamentary democracy; guided democracy; the new order; and post new order. Historic events marking the presence of local politics in Indonesia will be described in the following section.

In the era of democratization of a country, both leadership transition and legislative regulations which are government policies must be aimed to efforts of enlighten democracy itself, so that the ability of the community must be awakened with soul awareness, to mature themselves and open up insights to understand the state and community. According to Udoji in Wahab (2005: 17) states that "Although in reality what differences are expected from policy makers with the reality of the achievement of the implementation of the policy. This is influenced by the ability of the organization or actor who carries out policy decisions".

\section{References}

Halim, Abd. (2014). Politik Lokal, Pola, Aktor dan Alur Dramatikalnya (Perspektif Teori Powercube, Model dan Panggung). Gamping, Sleman, Yogyakarta: Lembaga Pengkajian Pembangunan Bangsa (LP2B).

Irawan, Maksudi, Beddy. (2012). Sistim Politik Indonesia (Pemahaman Secara Teoritik dan Enoirik), Jakarta: PT. Raja Grafindo Persada.

Wasistiono, Sadu and Wiyoso Yonatan (2009). Meningkatkan Kinerja DPRD, Bandung: Komp Panghegar, Fokusmedia.

Silalahi, Ulber and Syafri Wo rman. (2015). Desentralisasi dan Demokrasi Pelayanan Publik, Bandung: IPDN Press.

Ambar Teguh Sulistiyani. (2004). Memahami Good Governance Dalam Perspektif Sumber 
Daya Manusia. Yogyakarta: Gava Media.

Agustino. (2008). Dasar-dasar Kebijakan Publik. Bandung: Alfabeta.

Bungin, M. Burhan. (2008). Penelitian kualitatif; Komunikasi, Ekonomi, Kebijakan Publik, dan Ilmu Sosial Lainnya. Jakarta: Kencana.

Eko Prasojo, at el. (2007). Pemerintahan Daerah, Jakarta: UT.

Iswanto, Yun. (2005). Manajemen Sumber Daya Manusia. Jakarta: UT, Departemen Pendidikan Nasional.

Islamy, M. Irfan. (2007). Prinsip-Prinsip Perumusan Kebijaksanaan Negara. Jakarta: Bina Aksara.

Koentjaraningrat. (2009). Metode Penelitian masyarakat. Jakarta: MMPM, Pustaka Utama. Moleong, Lexy. J. (2014). Metodologi Penelitian Kualitatif. Bandung: Remaja Rosdakarya. Nugroho. (2009). Implementasi Kebijakan. Bandung: Alfabeta.

Purwanto. (2007). Teori Organisasi. Jakarta: UT.

Santosa. (2012). Administrasi Publik (Teori dan Aplikasi Good Governance), Bandung: PT. Refika Aditama.

Sedarmayanti. (2014). Manajemen Sumber Daya Manusia (Reformasi Birokrasi dan Manajemen Pegawai Negeri Sipil). Bandung: PT. Refika Aditama.

Soetanyo. (2010). Metode penelitian Kualitatif. Bandung: Remaja Rosdakarya.

Sondang P. Siagian. (2010). Kiat Meningkatkan Produktifitas Kerja. Jakarta: Rineka Cipta.

Subarsono. (2010). Analisis Kebijakan Publik (Konsep, Teori dan Aplikasi). Yogyakarta: Pustaka Pelajar.

Sugiyono. (2011). Metode Penelitian Kuantitatife, Kualitatife, dan $R \&$ D. Bandung: Alfabeta. Winarno. (2005). Teori dan Proses Kebijakan Publik. Yokyakarta: Media Presindo.

Persandingan Undang-undang-undang Dasar Negara Kesatuan Republik Indonesia Tahun 1945, Satker Sementara Penguatan Kelembagaan Komunikasi dan Informasi NAD-Nias, 2006. 